\title{
Role of Macro-Economics in Minimizing Obstacles to Sustainable Development (Islamic Perspective)
}

\author{
Ibrahim Mohammad Khrais ${ }^{1} \&$ Ismail Y. Yamin ${ }^{2}$ \\ ${ }^{1}$ Economics Associate Professor, Faculty of Economics, Zarqa University, Jordan \\ ${ }^{2}$ Finance Associate Professor, Faculty of Economics, Zarqa University, Jordan \\ Correspondence: Ibrahim Mohammad Khrais, Economics Associate Professor, Faculty of Economics, Zarqa \\ University, Jordan. E-mail: i_khrais_economic@yahoo.com
}

Received: May 25, 2017

Accepted: July 4, 2017

Online Published: July 20, 2017

doi:10.5539/ijef.v9n8p179

URL: https://doi.org/10.5539/ijef.v9n8p179

\begin{abstract}
Economic development occupies a significant status is Islam, as Muslims are commanded to settle and advance the earth. Since anything required to perform a duty is a duty itself, settling the earth can be achieved only by development, which can be achieved by production. The latter builds the earth and assists man in worshipping God.

The present paper concentrates on the role of macroeconomics in accomplishing economic development from an Islamic perspective. The Noble Qur'an verses and Hadith traditions are reported from specialists in a bid to provide the sought complete picture.

Section One investigates the capitalistic view to solve economic crises, which represent the major obstacle to any stage of development. Section Two defines economic development from an Islamic perspective, as well as the criteria set to solve relevant problems. Section Three explores the obstacles to sustainable development in the Islamic World and proposes solutions to alleviate them.

This brief study sheds light on the Islamic approach to (sustainable) development, showing the resulting public economic welfare, which would be definitely reflected on individual well-being.

The major conclusion that sustainable development is a comprehensive concept associated with the continuity of economic, Poverty and unemployment are the most crucial obstacles that hinder sustainable development.
\end{abstract}

Keywords: sustainable development, capitalism, Islamic perspective

\section{Objectives of the Research}

The paper investigates the foundations of the Islamic economic thought in viewing economic development. Focus is laid on the realizing the principles of settlement, earth construction and self-dependence in all the life aspects, in terms of necessities, needs and betterments.

\section{Research Methodology}

The inductive and deductive methods are employed to review the main features of economic development, aiming at the complete picture of the macroeconomics role from an Islamic perspective.

\section{Theoretical Framework}

\subsection{Capitalistic Perspective of Economic Development}

Rather than development, Growth was the dominant term before the World War II. Economic growth refers to an increase in the national product without deliberate change in the performance of the economy. On the other hand, economic development is a multi-faceted process represented in economic and social structures. In this integrated process, the economic part is aimed at raising the society's real national income, while the social part is aimed at making social, cultural and political differences. According to capitalists, economic development in this framework is wider than growth, for the latter is not based on structural explanations. Another difference is that the former cares for both quantity and quality, while the latter cares only for quantity. A third one is that the former is planned by states to bring in economic and social changes, while the latter is unplanned. (Al-Fangary (1981). 
In spite of the above, some economists do not believe in such a distinction. They argue that development and growth are synonyms of the very same phenomena. Historically speaking, the term Economic Development started to dominate with the wane of the economic liberty philosophy and the rise of the state intervention and economic planning approach.

The concept of development went through several stages due to the evolution of capitalism itself. According to the classical thought, national income was the centre of the definition: "a notable increase in national income and its per capita share, distributed to the different activities and income categories, continuing over a long period of a generation or two, and taking a cumulative form."

In the modern times, development has become more broadly defined as: "a set of economic, social and cultural procedures aimed at building an internal economic mechanism, which would maintain a real continuing increase in the gross product and a persistent rise in the real per capita income, and which is aimed at a fair distribution of such product between the different social classes working to achieve it."

In addition, this concept was affected by the failure of the capitalistic experiences in the developing countries. These nations called for a concept that emancipates them from economic dependency, leading to the emergence of Independent Development for self-growing economic entities. So, Independent Economic Development refers to self-reliance through the ability to think and act independently, relying on improving domestic resources in meeting a major part of the main requirements. Such liberation in self-reliance for development is the essence of the battle for pursuing national liberation which began in political independence. While independent economic development does not reject cooperating with and benefiting from others, it should take the form of integration and exchange of advantages rather than submission (Saleh, 2014).

Other than the failures of capitalistic development in the developing countries, such experiences led to development problems in some advanced countries which adopt capitalism. Among these are associated with the environment and the lack of resources and diet, a natural outcome of the capitalistic development policies wasting resources and polluting the environment.

In the early 1980's, a new development concept was proposed to tackle pollution and rationalize resources for the generations to come. It was called Sustainable Development. It was defined as the continued effort to improve the human life, taking into consideration the environmental system capabilities. A wider definition was proposed by the FAO conference as "the management and conservation of the natural resource base, and the orientation of technological and institutional change in such a manner as to ensure the attainment and continued satisfaction of human needs for present and future generations. Such sustainable development conserves land, water, plant and animal genetic resources, is environmentally non-degrading, technically appropriate, economically viable and socially acceptable."

\subsubsection{Capitalistic Perspective to Solve the Economic Development Problem}

Capitalists argue that the economic problem lies in the limited resources against the increasing human needs. For them, the scarcity of nature does not meet the various renewed wants.

The crisis elements are as follows:

a. Assigning and relatively prioritizing the needs of the society in terms of commodities and services

b. Organizing production

c. Distributing production

d. Ways of maximizing production factors and developing production mechanisms, while keeping the factors' full employment in advanced countries

e. Rise of consumption rates, while domestic production is weak and growing too slowly in developing countries

\section{f. Production factors not fully employed in developing countries}

g. Excessive use of resources by advanced countries, affecting the environment and needs of new generations as well as reducing food.

According to capitalism, the solution lies in economic liberation in its broad sense: the individual's freedom of possession, utilization and consumption. Liberty is the main motive to employ the capitalistic economic system and the source of economic balance. It is the market mechanism which answers all the questions of the problem (Al-Fangary, 1981).

Capitalism has tried to solve the development problems in the developing countries as well as the imbalances of 
advanced capitalistic economy. Classical thinkers chose the point of departure to be the division of labour principle, which raises the laborers' technical and productivity levels. Better and more efficient means should also be provided to save the production time and cost, provided that the capital is the axis of the economic activity. In addition, rather than the state intervention, both economic liberty and the supply and demand mechanism should be the motive (Al-Ashwah, 2004).

The solutions of modern capitalistic though emerged upon the Recession crisis (1929-1933), which was one of the dark times of capitalism. That period showed that the imbalances of the system are not actually found in the supply of commodities and services - in which most economist are interested - but in real demand. At that time, it turned that the insufficient market in terms of demand is the essence of the capitalism problem. Earlier, specialists cared for minimizing the costs of the produced units and maximizing the profits of individual organizations, arguing that the achieved profits are the source of capital accumulation.

To solve the problem, Keynes explored national economy and its required conditions to grow. He considered real demand the main axis of economic development. He called it Effective Demand and defined it as "the part of national income spent on consumption and accumulation". He set the variables affecting the national income growth and several major economic growth issues. He also founded a relationship between the rise of investments and the national income growth, terming it as the Multiplier, which indicates the impact of investment. Further spending in this direction would multiply national income, other than the initial rise of investment due to the resulting persistent spending on consumption.

After Keynes, some theoreticians were keen on proposing solutions to the development problems, looking into Structural Development - which emerged in the 1950's. Authors like Paul Rosenstein, Nurkse and Arthur Lewis interpreted such a situation in a state of imbalance of payments, unemployment and unfair income distribution based on specific features of demand and production functions. Such structuralist theories argue that the composition of production, labour and trade are keys to comprehend the economic development problems. For instance, a very simple structural form represents a dual economic model (agricultural and industrial sector).

The Modern perspective states that the above capitalistic theories deepened backwardness in the developing countries, rather than helping them. These theories relied on dependency in interpreting development, as is obvious in the foreign trade propositions by Ricardo and improved by the Heckscher-Ohlin model - which was in favour of the developed countries' foreign trade. Economies flourished in the states which relied heavily on themselves in terms of internal resources and mobilizing their human and natural capabilities, independently from external assistance. Here, it is safe to say that the (former) Soviet Union and Japan were the top examples. As a result, the developing countries began to adopt self-reliance to tackle such issue away from the fear of economic submission resulting from carrying out the capitalistic vision of development, thus calling for Independent Development.

While the developing countries suffered from the consequences of economic dependency because of capitalism, wealthy capitalist countries failed in putting an end to the development problems. In fact, new issues emerged, such as environmental pollution, lack of resources, training and diet, further poverty and recurrent recession crises, especially that of the 1930's. The hard dilemma has come back not only to affect capitalistic states, but also all those which this thought attempted to be its satellites (Saleh, 2014).

In reality, capitalism is still unable to solve the economic problems through the price equilibrium, for the capitalistic economic development is associated with a consumer who does not feel full and a producer whose production is limitless and freedom absolute. In other words, while the former looks for maximum delight, the latter aims at maximum profit. This approach ignores values, morals and religion in its transactions. It does not care whether the product is good or evil, useful or harmful, let alone whether the profit comes out of exploitation or fairness, cheating or honesty. The only target is further wealth.

\subsection{Islamic Perspective of Economic Development}

\subsubsection{Tanmiya (Development) in Arabic}

Tanmiya is derived from Nama (increased), indicating quantity and quality growth. Tanmiya means to bring about more. In the Noble Qur'an, on the other hand, the term Zakat refers to growth, increase, goodness, purity, plantation, raising, rising and manifestation, which is broader in terms of quantity and quality than mere increase. Allah says: "Indeed he succeeds who purifies his ownself."

He also says: "Take Sadaqah (alms) from their wealth in order to purify them and sanctify them with it." There is also: "And We cause therein the grain to grow", where the stem nabata means rose, grew and increased. Allah also says: "Then We brought forth for you therewith gardens of date-palms and grapes", where the stem Nasha'a 
refers to generation, rise and raising, which is close to development and growth.

\subsubsection{Iqtisad (Economy) in Arabic}

In the Arabic language, the term Tanmyia is combined with Iqtisad to make Tanmiya Iqtisadiyya. The latter is derived from Qasd. Of men, it means that is in between fat and thin. Of matters, it is not extreme. Of walking, it is medium. Of spending, it is in between stinginess and dissipation. Allah says: "And be moderate in your walking", which is not slow nor fast. He also says: "And upon Allah is the responsibility to explain the Straight Path", where it refers to the right way. He also says: "Then of them are some who wrong their own selves, and of them are some who follow a middle course, and of them are some who are, by Allah's Leave, foremost in good deeds", to refer to a middle way between extremism and carelessness. Allah also says: "Had it been a near gain (booty in front of them) and an easy journey, they would have followed you", where Qased is neither close nor far away. Thus, it is about moderateness and straightness. Someone who is Muqtased is moderate in spending. Prophet Mohammad (Peace and blessings of Allah be upon him) says: "He who is moderate in spending will not be poor." There also Maqsad (end or destination), referring to the heading to something in a straight, rather than slanted, way. In addition, among the main purposes of the application of the Islamic Shari'a is to accomplish the interest of people in this life and the Hereafter, in order to settle the earth, by means of providing benefits, preventing harms and purifying the society from evils.

\subsubsection{Islamic Economics Definition}

Islamic economics is a discipline based on divine teachings to provide a scholar with the Shari'a foundations derived from the Noble Qur'an and Qudsi and Prophet Mohammad's Hadiths. These basics are economic constants which can be phrased in the form of a guided theory for specialized research. An Islamic theory of economics is an accumulation of knowledge aimed at attaining an ultimate status possible within the human capabilities employed in relevant attempts. The thought that is merely produced by humans is narrower than the comprehensive knowledge of the constant discretionary, empirical and applied thought derived from the Shari'a foundations (Qur'an and Hadith). In other words, Islamic economics is based on two pillars. The first is constant because it is from Allah. The second is variable because it is about analysis and application. As research in economics combines revelation and reasoning, the Islamic economic theory makes no mistakes as well as it is valid for implementation across time and space (Khrais, 2015).

Thus, it is safe to define Islamic Economics as: "a discipline that aims at establishing laws, principles, obligations and theories which is valid for the Shari'a implementation to achieve maximum benefit for mankind."

\subsubsection{Economic Development in Islam}

Islam cares about development and uses a deeper meaning. The 'imara (construction) of earth is a worship of Allah, who makes it a task of settlement. Allah says: "He brought you forth from the earth and settled you therein," which means he entrusts you to construct it. Al-Jassass, an exegete of the Noble Qur'an, says this verse indicates the obligation of constructing the earth in farming and building. Al-Qurtubi, another exegete, says it is an absolute command of construction by God - which indicates an order. Such a concept of construction is aimed at creating a community of pious people which would employ the resources provided to enjoy a decent standard of living, along with the feeling fear of Allah.

Early Muslims, especially thinkers, used the term 'imarat Al-ard to indicate economic development. An example of a letter by a caliph is that one from Ali bin Abi-taleb to the governor of Egypt: "Let your consideration of the earth construction higher than that of bringing in taxes, since the latter is only achieved by the former. However, whoever asks for taxes without construction destroys the country." In other words, the wider the construction, the better the people's productive activity in all its forms and the higher the resulting income. Development in Islam appears in its target, limited in the Shari'a's five main purposes: faith, self, offspring, mind and money. Furthermore, justice shall be accomplished for the whole mankind through the fair distribution of resources.

In both modern and old Islamic thought, Ibn Khaldoun seems to be the best author to explicate the concept. When he elaborates on construction, he argues that it is based on the population variable on any piece of land. The more the inhabitants, the broader the construction, and vice versa. Residents - by nature - attempt to meet their needs of food, drink, clothes and dwelling. Therefore, they cultivate the land, establish various industries and set up buildings. When these people cooperate and divide labour, they get of their productive efforts much more than their needs. Moreover, Ibn Khaldoun believes that construction depends, other than the population, on the people's expectations according to the prominent political and economic atmosphere of the society. If it is a free state which only collects religious duties like Zakat, then their expectations will broaden, production will 
grow, markets will widen and profits will increase. In contrast, if the state is tyrannical, exaggerates in collecting taxes - other than Zakat - and rivals people over their own business, then economic devastation will take place (Al-Ashwah, 2004).

Some modern economists attempt to define development in Islam to come closer to the contemporary literature. Yousef, for instance, defines Tanmiya in Islam as high production and fair distribution. Dunya adds that the Islamic and people's definitions only differ in that the former includes purifying worship to Allah. On his part, Afar remarks that development in Islam is associated with improving production and the wealth of the society in order to achieve the main purposes of the Shari'a. In addition, it is concerned with providing the requirements of man's dignity, firstly, and then other cultural and material needs. As for Khorshid, development is related to the ultimate use of economic resources, offering sufficiency and eliminating poverty. According to Ahmed Safiyyiddin, development is the study of the ways of earning and spending in light of the rulings and ethics promoted by the Shari'a of Islam. Finally, economic development is defined by the Theoretical and Practical Encyclopedia for Islamic Banking as the study of the tools employed by man to meet the individual and societal needs of this life in accordance with a Shari'a specific methodology.

Based on the above, economic development can be defined as: "the set of the Shari'a rulings, standards and tools adopted in constructing the earth in order to meet the human society's needs in this life and the Hereafter and to serve the worship of Allah."

\subsubsection{Islamic Perspective to Solve the Economic Development Problems}

The Islamic solution perspective is based on the view of the problems. It is not believed to be the lack of resources or stinginess of nature, as argued by capitalists. Allah has granted these resources to man to use them whenever he needs them. In fact, it is about man's injustice against himself and denial of Allah's blessings. Allah says: "Allah is He Who has created the heavens and the earth and sends down water (rain) from the sky, and thereby brought forth fruits as provision for you; and He has made the ships to be of service to you, that they may sail through the sea by His Command; and He has made rivers (also) to be of service to you. And He has made the sun and the moon, both constantly pursuing their courses, to be of service to you; and He has made the night and the day, to be of service to you. And He gave you of all that you asked for, and if you count the Blessings of Allah, never will you be able to count them. Verily! Man is indeed an extreme wrong-doer, - a disbeliever." These verses stress that Allah has given man the resources sufficient to fulfill his material needs, but man himself wastes the chance by wronging himself and denying Allah's graces. This is obvious in unfair distribution in economic terms as well as in ignoring the investment of, and negative attitude to, nature (Khrais, 2015).

To solve the economic development problems, Islam has set some criteria associated with man himself and others with production, spending, exchange and distribution.

\section{1) Criteria related to mankind}

Man is the end and major means of human development. He is settled in the earth to construct it and worship Allah. Thus, he is prepared by Islam to carry out the responsibility of settlement, whose condition means using wealth for the service of the settled people in terms of utilization empowerment and benefit possession. Allah says: "And surely, We gave you authority on the earth and appointed for you therein provisions." He also says: "See you not (O men) that Allah has subjected for you whatsoever is in the heavens and whatsoever is in the earth, and has completed and perfected His Graces upon you, (both) apparent and hidden." To ready man for the duty of the earth construction, he is raised in a true Islamic manner and told that wealth actually belongs to Allah, who says: "And give them something yourselves out of the wealth of Allah which He has bestowed upon you." Man is also ordered to obtain wealth by Halal ways as well as adopt good production and good consumption (Al-Ashwah, 2004).

Man should believe that only Allah uses wealth however He wishes and man is only a trustee in this regard. Therefore, he should utilize and develop it as much as required to construct the earth, where he is settled. Allah says: "And it is He Who has made you generations coming after generations, replacing each other on the earth." According to Ibn Katheer's exegesis, it means He has made you build it generation after generation and successors after predecessors.

\section{2) Criteria related to labor factors}

In order for man to construct the earth, labour shall persist to develop or invest wealth, so that his needs are always fulfilled until the time of the Hereafter. Here, 'labour' refers to the continued effort of resource investment, multiplication of revenues for the welfare of the Ummah and support for its existence and coral 
values. It is also good work, which purifies the soul, promotes morals, broadens philanthropy and maintains each of faith, body, mind, wealth and offspring. Prophet Mohammad (PBUH) says: "If any Muslim grows a plant or tree, then anything eaten from it will be a charity." Thus, it is the work that maintains faith and life, constructs the earth, comes up with good production, secures dignified life for man and serves the settlement of the earth. Allah says: "God has promised to appoint those of you who believe and perform honorable deeds as [His] representatives on earth, just as He made those before them into (such) overlords, and to establish their religion for that which He has approved for them, and to change their fear into confidence They serve Me [Alone] and do not associate anything else with me." In addition, Prophet Mohammad says: "Verily, Allah loves a believer with a career."

Upon the spiritual and technical training of man, job opportunities shall be created and imposed on each capable person. In other words, individuals are urged to earn a living by means of labour, for the only real course of development is the mobilization of human capabilities in the various production areas. For example, the reclamation of a deserted land makes it a property of the initiator. Prophet Mohammad (PBUH) says: "He whoever reclaims a land which belongs to nobody is entitled to own it." "urwa said Omar bin Al-Khattab ordered this during his term. Islam provides a job to each capable person to guarantee the utilization of all the community's production resources, considering this one of the ruler's duties towards his citizens.

3) Production and spending criteria

In Islam, production is defined as "the use of the capabilities granted by Allah in mankind to deal with the material resources also granted by Allah in the earth, so that a benefit approved by the Shari'a is found." Production is aimed at providing the needs which assist a Muslim in worshipping Allah. Ibn Khaldoun argues that diet shall be available for humans to survive, need is the major motive for production and an individual's ability does not secure sufficient diet. Therefore, human labour shall be meticulously organized by the community in a way that maintains sufficient production for everyone. According to Ibn Khaldoun in the section addressing the significance of the farming evolution from rural to urban areas, Islam also calls for the division of labor and links the extension of the need to that of the society.

Production takes place through a real investment aimed at projects creating the good commodities required by the members of the society, bearing in mind a deep understanding of the nature of money. As money itself does not beget money, but grows through actual participation and complete standing for the risk in the economic activity. As a result, Islamic banking is currently based on this principle. An Islamic bank would not trade in money by performing financial mediation on the basis of loan, debt or credit between creditors - or depositors and debtors, i.e., consumers and producers. It rather acts as a real investment company whose relationship with clients is governed by a speculation contract. Here, money is paid by its owner to another person to invest it. While profit is distributed upon condition, the entire loss is borne by the money owner and the speculator or worker loses his effort. Therefore, the depositors would be the capital owners, while the bank is the speculator or laborer. So, if there is a loss without effort by the bank, it is totally borne by the depositors. This part of risk makes it Halal (permissible) for the depositors to get part of the profit, if any, according to the deal (Khrais, 2015).

The main role of the ultimate utilization of resources and brining about of development is the integration and cooperation of the state and private sector (members of the society) according to the Islamic priority system. Wealth, i.e. resources, is employed accordingly in a balanced, comprehensive manner without any dissipation of potential or energy.

\section{4) Market criteria}

The economic activity shall mobilize development through the Islamic market on the basis of the mechanisms (of pure competition) which practically lead to (fair) transactions and then to higher production and better quality by means of fair trade-offs and straightforward investment participations. Philanthropy, piety, mutual advice, control and guidance shall dominate the market (supply and demand) through the price mechanism, while attempting to remove any defects affecting the flow of supply and demand, such as monopoly, cheating and financial corruption.

Scholars of Fiqh have different views of pricing. Those who support it cite Imam Malek's narration of Omar's command to Hateb bin Abi-Balta'a. When he saw Hateb selling raisins in the market, he said: "You either raise the price or you will be led out of our market."

In addition, market dealers should learn the transaction rulings. Omar also said: "Only those who are educated in Fiqh shall sell in our market." Furthermore, the market shall be based on the fair value standards and honesty. 
Prophet Mohammad (PBUH) says: "An honest, trustworthy Muslim merchant will be with martyrs on the Day of Judgement." So, such a market never knows scanting nor underestimation. Allah says: "Woe to those who give less in measure and weight, Those who, when they have to receive by measure from men, demand full measure, And when they have to give by measure or weight to men, give less than due." Monopoly is also prohibited. Prophet Mohammad (PBUH) says: "He who monopolizes is a wrong-doer." Nor shall there be usury. Allah says: "O you who believe! Be afraid of Allah and give up what remains (due to you) from Riba (usury) (from now onward), if you are (really) believers." When there are differences between parts of land, there should be commercial exchange. "And in the earth are neighbouring tracts, and gardens of vines, and green crops (fields etc.), and date-palms, growing out two or three from a single stem root, or otherwise, watered with the same water, yet some of them We make more excellent than others to eat. Verily, in these things, there are signs for the people who understand." Prophet Mohammad (PBUH) says: "He who brings in a commodity to a country and sells it for that day's price will gain a reward of a martyr." However, exchange shall be equivalent between countries, away from any form of subordination or waste of resources (Khrais, 2015).

\section{5) Distribution criteria}

The product shall be distributed according to (fair) standards which fit the effort exerted, risk taken or sought social solidarity. One of these is wage for a labourer. Another is insurance for the risk whether in terms of profit or loss of money and for the one who takes it (speculator). A third is need, for those who have partial or full disability, taking into consideration the responsibility of the state and other members of the society in distribution and re-distribution in light of this standard to secure a decent living for the poor. Thus, distribution is one of the pillars of development in Islam (Al-Gazali, 1988).

Distribution shall also be carried out in the different forms of charity, such as Zakat - in the first place - alms and penances in a bid to achieve fairness of the use of money, organize social solidarity and guarantee premium utilization of wealth. Allah says: “.... and spend something out of whatever He has let you inherit [from anyone else]. Those of you who believe and spend [on charity and in public service] will have an even larger fee." He also says: "Take Sadaqah (alms) from their wealth in order to purify them and sanctify them with it." Prophet Mohammad (PBUH) says: "Allah decrees alms from their wealth to be taken from their rich back to their poor people." He also stresses that: "Money never decreases by paying alms." In terms of the prescribed destinations, Zakat is aimed at redistributing income in favour of poor classes to help raising their contribution to the production, on the one hand, and their consumptive spending, on the other. That would increase real demand, refresh the economy and promote investment and production. Here, scholars of Fiqh agree that anyone capable to earn a living through any profession shall be given only what he needs to continue with his way of earning. Omar said to his governors: "When you give, satisfy people." Finally, a capable person with his effort and wealth to earn a living shall not be given Zakat, as Prophet Mohammad (PBUH) says: "Alms is not permissible for anyone who is rich or of a healthy, strong body."

\subsection{Islamic Perspective of Sustainable Development}

Sustainable Development began to circulate at the national and international levels among relevant terms, such as globalization, clash of civilizations, modernism, post-modernism and human development. All the aforementioned need to be carefully understood, so that we can find a common language with the rest of the world without any kind of confusion. Some concepts could take different meanings and interpretations according to each country, culture, originator or analyst. Not only would that cause ambiguity to ordinary people, but also for the specialists themselves.

\section{First: Foundations of Sustainable Development}

Tanmiya (development) is included in the meaning of settlement. Allah says: "He brought you forth from the earth and settled you therein."

According to exegetes, the above verse commands construction, where a general command often conveys obligation. As is cited above, Ali bin Abi-taleb said to the governor of Egypt: "Let your consideration of the earth construction higher than that of bringing in taxes, since the latter is only achieved by the former. However, whoever asks for taxes without construction destroys the country."

Another relevant Qur'anic term is Tamkeen (empowerment). Allah says: "And surely, We empowered you on the earth and appointed for you therein provisions."

Scholars of high argue that Tamkeen has two meanings: to adopt a decision, space and home, and to (be able to) control. Therefore, Allah has prepared us to hold control over nature and commanded us to carry this out. In other words, he told us to produce technological devices as a means to control natural conditions for the benefit 
of man.

The Islamic view of sustainable development fundamentally cares about man as both producer and major beneficiary of development. He is part of the universe, but is honored and preferred to many of Allah's creations. Allah says: "And indeed We have honored the Children of Adam, and We have carried them on land and sea, and have provided them with At-Taiyibat (lawful good things), and have preferred them above many of those whom We have created with a marked preference." Thus, not only is he a consumer, but also a producer for his own and for others.

In spite of man's authority over the environment resources with which Allah entrusted to serve his interests, man's possession is not absolute. In other words, as these are blessings and mercies of Allah, he should be thankful by believing in their creator and utilize them in what benefits the earth and constructs the universe, rather than using them to harm others, such as in causing pollution. This right of possession is limited by the rulings of Allah and rights of the society, and such a right could be taken away for the general interest. This means that an individual is a trustee for the group in guarding, investing and spending wealth. If he abuses wealth, the group is entitled to stop him. Allah says: "Believe in Allah and His Messenger (Mohammad), and spend of that whereof He has made you trustees." He also says: "And give them something yourselves out of the wealth of Allah which He has bestowed upon you."

Since they affect environmental balance, today's forms of abuse to natural resources are forbidden in Islam. For instance, overgrazing leads to desertification. Another example is the use of chemical insecticides, killing many birds and causing the extinction of several wild animals like foxes and owls, which used to feed on rats. An imbalance emerged when rats harmed farms. A third is the phenomenon of acid rain, suffered by northwestern Europe, destroying $16 \mathrm{~m}$ acres of forests through 9 countries.

What is needed now is the moderation of the natural resources exploitation. Allah says: "Thus We have made you the best nation, that you be witnesses over mankind and the Messenger (Mohammad) be a witness over you."

Islam prohibited extravagance in utilizing the graces of Allah. He says: "O Children of Adam! Take your adornment, while praying and going round the Ka'bah, and eat and drink but waste not by extravagance, certainly He (Allah) likes not those who waste by extravagance.”

Such dissipation is a kind of corrupting the earth, which is also forbidden. Allah says: "So fear Allah, keep your duty to Him, and obey me. And follow not the command of Al-Musrifun [i.e. their chiefs, leaders who were polytheists, criminals and sinners], Who make mischief in the land, and reform not."

\section{Second: Major Obstacles to Sustainable Development in the Islamic World}

\section{1) Poverty and cumulated debt}

According to the World Bank reports, there are less people under the poverty line ( $\$ 1.25$ per day) in the 57 member states of the Islamic Conference Organization in the $1^{\text {st }}$ decade of the $21^{\text {st }}$ century. They dropped from 396 million to 322 million by $18.7 \%$ (74 million people).

In spite of the relative improvement, the 2015 report showed that these countries' share of the world's poor people is so high. In 2011, they still hosted 33.1\% (973 million) in contrast with 22\% in 1990. Moreover, due to social ups-and-downs in some member states, experts fear the figures are likely to rise.

The study, published by the Islamic International News Agency (IINA) on December 10 2015, the geographical distribution of poverty in the ICO states has not seen any noticeable change over the last two decades. Except for South Sahara, which was the slowest in progress, all the regional groups of the organization witnessed lower poverty rates (Regional Reports, 2014).

The statistics also show that $59 \%$ of the ICO's poor people live in the lower-medium-income countries, while the rest $41 \%$ live in low-income countries. The latter were much slower in the last two decades in decreasing poverty than in medium- and high-income countries. Between 1990 and 2011, the latter saw a decline of only 4\%, while in medium and high-income countries it went down by $73 \%$, and in low-income countries by $26 \%$ (Regional Reports, 2014).

The study attributes the phenomenon to several factors, some of which are manageable and some associated with weak administration of demographic, economic, environmental, social and political aspects. Poverty itself is divided into two types. The first is a human, dependent on measuring the income size, as is adopted in the above statistics. The second is multidimensional, based on important factors at the family level, such as education, health, properties and health. 
The document - titled "Measuring Poverty in the ICO Member States" and issued by the Statistical, Economic and Social Research and Training Centre for Islamic Countries (SESRIC) - found 214 million of the second type, making $68 \%$ of all poor people of the Islamic World.

Finally, the South Saharan states were found to host $46 \%$ of ICO's multidimensional poor people (98 million), followed by South Asia 37\% (173 million). East Asia and the Pacific came third and the Middle East and North Africa came fourth each by $15 \%$. About $77 \%$ of them concentrated only in 10 countries.

\section{2) Unemployment}

It has been a significant challenge to development in the ICO member states. It is no longer a mere economic problem, but a serious social issue affecting the people's security. Statistics indicate that unemployment rates among the youth in the Islamic World are much higher than the global average, which necessitates the creation of more than 85 million job opportunities in the region over the next 10 years. Islamic countries are urged to build the capabilities of the unemployed, while providing them with further chances to encourage their dynamic contribution to economic activities.

In its latest study, the ICO made expectations about unemployment for 2015 in the Islamic World in light of the ILO's Global Labor Trends report of 2014. In the period 2000-2012, the member states saw higher rates than the world average, ranging between $7.6-8.8 \%$ of the total workforce in contrast with the general average less than $7 \%$.

Such rates within the ICO vary according to the social, economic and political conditions of each state. For instance, in Qatar, it is less than $1 \%$ of the total workforce (0.6) - the lowest throughout the world. The same applies to Benin (1\%) and Kuwait (1.5\%), who come among the lowest ten world countries in unemployment. On the other hand, the following states suffer much from the problem: Mauritania (31\%), Palestine (23\%), Guyana (21.7\%), Gabon (20.3\%) and Yemen (17\%), where many economically active residents cannot employ their potential.

The Arab ICO countries are witnessing the top world average among the youth by $25 \%$, in contrast with $12.9 \%$ around the globe. Their share of the workforce is only 35\% in contrast with 52\%. Due to demographic considerations, these states need to create 35-40 million jobs just to keep the current average (Regional Reports, 2014).

3) Lack of technical capabilities and experience and up-to-date technology appropriate for the local conditions of several Islamic countries due to scarce financial resources

A relevant example is the amount of money spent on education unlike advanced countries. In reality, most Islamic countries are far away from integrating all children in elementary schools, though they promote mandatory education. For the next stage, in general, the capability of the secondary schools is insufficient to contain students. It is found that, although elementary school students could amount to $90 \%$ or more in some countries, secondary school students may fall to $25 \%$. As a result, the source of technical experience is weak, let alone the human capital flight to advanced countries.

The gap between the education quality in the industrialized and developing countries, including the Islamic World, is widening. According to statistics, in 1960, countries of Western Europe used to spend per student 14 times the amount in developing countries. However, in 1980, it became 50 times. That would, definitely, lead to disparities in the educational process inputs and technical requirements and, thus, on the scientific and skills levels of the output. There also the quality gap between the countries of the North and South - embodying the so-called knowledge gap between wealthy and poor states - and even between the rich and poor of the same country (Saleh, 2014).

4) The association between human development and sustainable development

Such a relationship is attributed to the dire need to strike a balance between the population and available resources. The following constitute barriers to the projects of sustainable development: (Al-Hassan, 2011).

- Weak capital for the investment in production sectors

- Common unemployment, mainly among the youth

- Low contribution of the industrial sector in the GDP, in contrast with a high share by the initial sectors such as agriculture, fishing, grazing and wood cutting

- $\quad$ Soaring illiteracy rates

- Population explosion 
- Economic dependency on foreign powers

- Reliance on a single national commodity for export

- Country to city migration, and

- Investment of Arab wealth in Western countries, estimated at over $\$ 800 \mathrm{~m}$. It is noteworthy that investing in Islamic countries, though less profitable, is more secure.

5) Lack of matching between the population growth, on the one hand, and the available natural resources, on the other

For example, the usable land in most Islamic countries is limited, amounting to 31.9\% in Syria and 6\% in Egypt. It is even lower in Algeria and Sudan, and the lowest in Saudi Arabia (0.5\%). Such population pressure leads to the expansion of farming in natural grazing areas and rain fed agricultures. The results are higher rates of overgrazing and desertification throughout the Islamic World.

\section{Third: Macroeconomic Solutions to Solve Problems of Sustainable Development}

\section{1) Economic Stabilization}

This could be achieved by means of full employment of resources to attain the interests assigned by the Shari'a. Firstly, natural resources should be invested by means of education to maintain mental energy as well as the scientific and meditative methods to utilize various experiences and studies. Secondly, financial resources should be consolidated by means of prohibiting usury and treasuring as well as imposing Zakat. That would speed up the circulation of money and raise the efficiency of the capitals' investment in legal ways. As a result, a balance would be struck between the money supply and demand, stabilize the currency exchange rate in internal and external transactions and achieve approximation or equivalence between investment and saving - which materializes in successful financial and monetary markets and. Thus, economic stability can take place (Saleh, 2014).

\section{2) Economic Development achievement}

Investment should be a priority of the Islamic economy as well as the achievement of balance and combination of different sectors, such as industry, trade and construction. In addition, necessary finance should be secured and difficulties overcome to maintain human needs, such as environment protection, basic commodities, research development and capital composition, so that overall economic development is accomplished under the principles of promoting the right and discouraging the wrong (Al-Makki, 2006).

\section{3) Re-distribution of Income and Wealth}

Poor families should be supported by possessing the necessary means of production and fair distribution of the available resources in terms of sector, geography and community.

Other than the main objectives of the Islamic monetary policy, there are minor targets associated with external economic activity. Firstly, a right balance of payments should be struck, by means of changing the rate of profit or monetary issue. That would alter the exchange rate and the balance of payments due to the movement of capitals, goods and services. Secondly, these payments should be sufficiently financed, liquidity provided for internal and external monetary and financial markets and foreign capitals attracted. Thus, overall economic and social development can be realized.

\section{4) Activation of Islamic Monetary Policy}

The monetary policy mechanism depends on the state of the economy. On the one hand, if the economy suffers from inflation, the money supply should be reduced in the national economy exclusively by the central bank through one or more of its various instruments at the same time. On the other hand, if there is recession, the central bank should do the opposite (Tabaybiyya, 2014).

The Islamic macroeconomic theory does not contradict the above. However, what is Haram (prohibited) of the monetary policy tools - such as the interest and discount rates - is excluded and replaced with the profit average and Zakat paid in advance. Therefore, the efficiency of the Islamic monetary policy lies in the ability of the competent authorities' legislation and procedures to manage the money supply, aimed at achieving monetary balance as well as mobilizing and investing the sector savings for stabilizing the money value.

Hence, the procedural effort of the monetary policy efficiency relies on the ability of the central banks' means to control the money supply to accomplish the monetary policy objectives. In other words, two parties hold such a responsibility: the central bank orders and regulates, and the banks carry out these measures. Between them there are the sought economic and social goals. 
In a bid to achieve the main objectives of the monetary policy, several basics should be provided, mainly:

- Establishment of a monetary authority (Islamic central bank)

This should be a governmental organization which regulates and issues money, oversees the banking institutions and sets the monetary policy in accordance with the Shari'a. It has certain functions, such as the responsibility for carrying out the Islamic monetary and financial system, and serving as the link between the state and Islamic banks and between the banks themselves. It is also the only body entitled to issue the monetary unit as well as guide and regulate the monetary and credit affairs. In other words, it is entrusted with the macro level, while banks and other financial institutions assume the micro level of saving, investment and all forms of partnership. These features need to materialize in an atmosphere of complete independence of the Islamic central bank's decisions and policy, since it is considered to be the top authority of the Islamic monetary system which is keen on the Ummah's public interest (Tabaybiyya, 2014).

- Provision and guidance of savings towards investment

The banking investment means employed should secure congruency between the development programs and plans, on the one hand, and the rule of profit and loss partnership, on the other.

- Regulation of money supply

Money shall only be supplied for the economic purposes associating the average of monetary expansion to the real growth average of national production. That would keep the value and stability of money as well as control the generation of credit money.

\section{Conclusions}

1) Sustainable development is a process of advancing land, cities, communities and business, provided that they meet the needs of the present without harming the capabilities of the generations to come to meet theirs.

2) Sustainable development - in reality - is a comprehensive concept associated with the continuity of the community's economic, social, institutional and environmental aspects. It empowers individuals and bodies to fulfill their needs and express their actual current presence.

3) Sustainable development includes human development to improve the levels of health care and education, in addition to participation by people to make the development decisions which affect their own lives.

4) Capitalism is still unable to solve the economic problems through the price equilibrium. This approach to economic development is linked to a consumer who does not feel full and a producer whose production is limitless and freedom absolute.

5) The Islamic perspective for the solution departs from viewing the economic problem itself. Here, it is not about the lack of resources or stinginess of nature, as capitalists argue. In fact, Allah provides sufficient resources but man wrongs himself and denies the graces granted to him by Allah.

6) Poverty and unemployment are most crucial obstacles that hinder sustainable development in Islamic World which could be result of mismanagement of economical, political and social factors.

\section{Recommendations}

1) The main role in the efficient use of resources and bringing about of development is to accomplish integration and cooperation between the state and private sector - i.e. individuals - in accordance with the Islamic priority system.

2) Without human development, there cannot be sustainable development. Such a relationship indicates the dire need for a balance between the population and available resources.

3) Efforts should be coordinated to put an end to unemployment, which is spreading among the youth. Strategic programs and plans should be set to create job opportunities to the unemployed, so that they would not be victims of intricate social and moral dilemmas.

4) To relate the process of issuing monetary with economical resources as the expansion averages of supplying monetary is connected with the real growing averages of domestic production.

5) To activate Islamic monetary policy tools and its usage in the economical imbalance situations for example Profit rate and ZAKAH value to eliminate the negative effects of traditional monetary policy tools.

6) To consolidate Islamic economical principles in full employment of economical resources, both of human and financial resources to achieve economical stability and sustainable development 


\section{References}

Al-Ashwah, Z. S. (2004). Islamic Economics: Theory and Practice. Cairo: Ghareeb Publication House.

Al-Fangary, M. S. (1981). Economic Approach in Islam. Riyadh: Ukath House.

Al-Gazali, A. H. (1988). Man as Core of the Islamic Approach to Economic Development (Islamic Economics Centre Publication). Cairo: Islamic International Bank.

Al-Hassan, A. R. M. (2011). Sustainable Development's Requirements. Paper presented to the governmental strategy forum to eliminate unemployment and achieve sustainable development at Mesilla University.

Al-Makki, S. (2006). Economics in Ibn Khaldoun's Introduction: Theory and Practice (2nd ed.). Tunis.

Khrais, I. (2015). Production and Development: Islamic Economic Perspective. Islamic Economics: Present and Future Challenges, 12, 407-419.

Saleh, A. M. (2014). Papers on Sustainable Development: Theory and Practice. ZU Journal, 14(2).

Tabaybiyya, S. (n. d.). Islamic Monetary Policies' Role in Achieving Sustainable Development. Paper presented to the $9^{\text {th }}$ International Conference of Islamic Economics and Finance, Qalam, Algeria.

UNDP regional offices. (2014). Regional Reports of Human Development.

\section{Copyrights}

Copyright for this article is retained by the author(s), with first publication rights granted to the journal.

This is an open-access article distributed under the terms and conditions of the Creative Commons Attribution license (http://creativecommons.org/licenses/by/4.0/). 